\title{
Risk Analysis of Partnership Broiler Farm in Blitar District, East Java, Indonesia
}

\author{
Septi Nur Wulan Mulatmi ${ }^{1,}$, , Apriliana Devi Anggraini ${ }^{1}$, Febrianti Shaywont Pratami ${ }^{1}$, \\ and Martina Motalova ${ }^{2}$ \\ ${ }^{1}$ Department of Animal Science, Faculty of Agriculture and Animal Sciences, \\ University of Muhammadiyah Malang, Jl. Raya Tlogomas no 246 Malang 65145, \\ East Java, Indonesia \\ ${ }^{2}$ Department of Infectious Diseases and Microbiology, Faculty of Veterinary Medicine, \\ University of Veterinary and Pharmaceutical Sciences Brno, Palackého tř. 1946/1, \\ 61242 Brno-Královo Pole, Czech Republic
}

\begin{abstract}
Contract farming is a form of business cooperation between two or more parties in a certain period of time to help farmers provide production facilities. The superiority of the partnership is as a partner to share the risk burden of production between core companies and small farmers. The risk of production in broiler chicken farming includes DOC quality, feed, and disease. Therefore, production risk management must be able to manage these factors well so they cannot cause losses. The material in this research is thirty partnership farmers in Blitar, East Java, Indonesia. The method used is a survey by observation and interview. The sources of data used are primary and secondary data sources from the results of interviews and observations. The analysis used is production risk analysis to determine the level of production risk in Blitar, East Java, Indonesia and descriptive analysis to find out the production risk management used by partnership farmers in Blitar, East Java, Indonesia. The results of this study can be concluded that the risk of production in Blitar, East Java, Indonesia is categorized as high risk caused by death. Meanwhile, production risk management carried out by farmers in Blitar, to reduce mortality is spraying disinfectants.
\end{abstract}

Key words: Contract farming, risk management, risk production

\section{Introduction}

Contract farming (CF) has attracted considerable at-tention over the past decades. Several studies show that CF increases farm productivity, profitability, farmers' income, and food security [1-3]. The partnership is a form of business cooperation between two or more parties (the core company and the breeder) for a certain period of time to assist the farmers in providing production facilities in the form of DOC, feed, medicines, vaccines, vitamins, and marketing of broiler products for mutual benefit. Given the large cost of broiler chicken production, the partnership can be a solution for small farmers to build a broiler chicken farming business [4]. The advantage of the partnership is as a partner for sharing the burden of production and marketing risk between the core company and small farmers [5]. Agriculture with a contract farming system have a negative impact on small farmers, including contracting, manipulation of inputs, contracts that do not benefit farmers (unprofitable contracts), manipulation of weighing (under weighing of poultry), giving an incorrect index or ranking, and grading problems [6]. The high volatility in production cost and the fluctuation price for broiler also become another cases. It was evidence that

\footnotetext{
* Corresponding author: septi.mulatmi@gmail.com
} 
majority $(91.2 \%)$ of poultry farmers practice with intensive farming system still low adopted risk management strategy.

The distribution of the risk burden on the partnership pattern between the company and farmers makes the small broiler farmers prefer the partnership, although the risks that occur during production cannot be avoided. One of the highest sources of risk is the source of production risk. Production risks in the business of broiler chickens include DOC quality, feed, and disease. Therefore, various production risks that can be caused by these production factors must be managed properly so that they cannot cause losses [7].

The role of broiler partnership scheme in mitigating market risks occurred in the sixth harvest time through financial performance achievement on the basis of high profit (IDR $399 / \mathrm{Kg}$ live body weight), the low category of enterprise and economic rentabilities (REnt $=4.07 \%$ and $\mathrm{REco}=1.68 \%$ ), and a limited payment capability toward total liabilities as the solvency level in the caution category (DTAR $=55.87 \%$ ) [8].

Broiler chicken farmers decide to partner to minimize risk, especially the risk of production during the maintenance period which is marked by the fluctuation of chicken mortality rates each period. Disease outbreaks often afflict broiler chickens and have a direct effect as a trigger for production risks. The disease is difficult to detect, can occur suddenly, and can cause high rates of mortality. If the temperature becomes too low, this causes the temperature of the air inside the cage to be high, causing high humidity in the cage. During the rainy season, the temperature in the cage becomes cold, and the air in the cage becomes humid. Conversely in the dry season, the temperature of the air inside the cage gets hot, carbon dioxide levels increase and the air in the cage feels more stuffy. Such conditions are difficult to avoid and result in death with a fairly high mortality rate. This can increase the breeding of germs in broiler chickens [9].

The economic feasibility of the production system increases with the level of welfare improvements for a sufficiently high price level for broiler meat and low volatility in producer prices. If this is not the case, however, risk attitudes of farmers become important as well as the use of potential risk management instruments. [10]

\section{Materials and methods}

This research was conducted in February 2019 to March 2019 in Blitar, East Java, Indonesia. Determination of this location was based on certain considerations of purposive sampling with the consideration that Blitar, East Java, Indonesia has a partnership system farm with a population of 5000 to 10000 broilers per plasma farmer.

The research method used in data collection is the survey method. The survey method was a technique of collecting data or information from a sample through interviews or filling out research questionnaires.

Some measures that could be used to measure deviations include variance, standard deviation, coefficient of variation, and lower-income limits [5]. Descriptive analysis was a method of examining the status of a group of people, an object, a condition, a system of thought in the present [6]. The descriptive statistical analysis aims to make a systematic, actual and accurate description, picture or painting of the facts, nature, and relationships between the phenomena being observed that were usually presented in the form of diagrams, graphs, etc. from the data that had been obtained from respondents using a questionnaire tool. The results of the descriptive statistical analysis obtained were used to determine the production risk management that was widely applied by partnership broiler farmers in Blitar, East Java, Indonesia. 


\section{Result and discussions}

\subsection{Characteristics of respondents}

The selection of respondent characteristics was one of the things that will affect the validity of the data to be used. Characteristics of respondents in the research conducted could be divided into four characteristics, i.e. characteristics based on age, education, and business scale.

The result showed that breeders in Blitar, East Java, Indonesia were still productive both physically and in developing their livestock business. Productive age had a higher level of productivity compared to workers who are old $[11,12]$.

The majority of farmers in Blitar, East Java, Indonesia have a high school/equivalent level of education. The higher the farmer's education level, the better the maintenance management because the farmer could adopt innovation and change the way of thinking and problem solving more mature [13].

The range of business scale owned by farmers in Blitar, East Java, Indonesia is on a business scale of 5000 to 7000 individuals. This includes a small and medium business scale.

Table 1. Characteristic of partnership broiler farmers in Blitar, East Java, Indonesia

\begin{tabular}{|c|c|}
\hline Parameter & Number of partnership broiler farmer (\%) \\
\hline Ages & 23.07 \\
\hline 21 to 30 & 46.15 \\
\hline 31 to 40 & 30.76 \\
\hline 41 to 50 & 26.90 \\
\hline Formal Education & 57.69 \\
\hline Junior High School & 15.38 \\
\hline Senior High School & \\
\hline Bachelor & 88.46 \\
\hline Business Scale & 11.53 \\
\hline 5000 to 7000 & \\
\hline 8000 to 10000 & \\
\hline
\end{tabular}

\subsection{Risk analysis}

Broiler chicken farmers decide to partner for risks minimizing, especially the risk of production during the maintenance period which is marked by the fluctuation of chicken mortality rates each period [14].

The value of variance shows that the greater the value of the variance, the greater the value of the deviation, the greater the risk faced in business activities [15]. The variation value obtained by partnership broiler farmers in Blitar, East Java, Indonesia is very large. These results indicate the level of risk of partnership broiler farmer production in Blitar East Java, Indonesia was very large.

The greater the standard deviation, the greater the risk faced [16]. The standard deviation value indicates the risk faced by partnership broiler farmers in Blitar, East Java, Indonesia is very large. The production risk was caused by high mortality rates caused by disease and restrictions on the use of Antibiotics Growth Promoters (AGP). 
Table 2. Variance calculation of partnership broiler farm

\begin{tabular}{|c|c|c|c|c|c|}
\hline \multirow{2}{*}{ Parameter } & \multicolumn{5}{|c|}{ Factors affecting production risk } \\
\cline { 2 - 6 } & $\begin{array}{c}\text { Average } \\
\text { gain }\end{array}$ & FCR & Mortality & $\begin{array}{c}\text { Age of } \\
\text { harvest }\end{array}$ & Benefit \\
\hline Variance (s $)^{2}$ & 169.26 & 113.83 & 0.14 & 51412.60 & IDR 2 616 917 654 478 460.00 \\
\hline $\begin{array}{c}\text { Standard } \\
\text { deviation (s) }\end{array}$ & 13.01 & 10.67 & 0.37 & 226.74 & IDR 51 155 817.00 \\
\hline $\begin{array}{c}\text { Expected return } \\
\sum_{i=1}^{n} E i \\
E\end{array}$ & & & & & IDR 9 233 333.00 \\
\hline $\begin{array}{c}\text { Variance } \\
\text { coefficient } \\
C V=\frac{s}{E}\end{array}$ & & & & & IDR 5.54 \\
\hline $\begin{array}{c}\text { Lower limit } \\
L=E-2 s\end{array}$ & & & & & IDR 93 078 301.00 \\
\hline
\end{tabular}

The expected return was obtained from the average net income throughout the observation period. The expected results depend on the income earned by the farmer each period. The current net income obtained by farmers is valued at IDR $1000 \mathrm{head}^{-1}$.

The coefficient of variation was a number that shows the comparison between the risk that might be borne with the cash income to be obtained or the coefficient of variance was used to compare the risks faced with the income received. The coefficient of variation showed that the risk borne by farmers is $554 \%$ of the return value obtained by farmers. This means that every IDR 1 income received will result in a risk of IDR 5.54. The coefficient value of variation greater than 0.5 indicated that the partnership broiler chicken farming business in Blitar, East Java, Indonesia had a large production risk in each period.

The lower-income limit showed the lowest nominal net income that a farmer might receive. If the lower-income limit was lower than zero, the farmer will suffer a loss. The lower boundary value showed that the broiler chicken farmers in Blitar, East Java, Indonesia suffer losses. The amount of the lower-income limit was caused by several cases of livestock death that could not be predicted every period. The difficulty of preventing mortality was a major factor in the high production risks experienced by partnership broiler farmers in Blitar, East Java, Indonesia.

\subsection{Risk management}

Efforts to reduce the high risk of production in broilers were to implement risk management. Corporate risk management was a way of dealing with all risks in the company without choosing certain risks. Risk management could be considered as a function of management. Several management functions were well known, namely Planning, Organizing, Directing, and Controlling (POAC) [17]. 


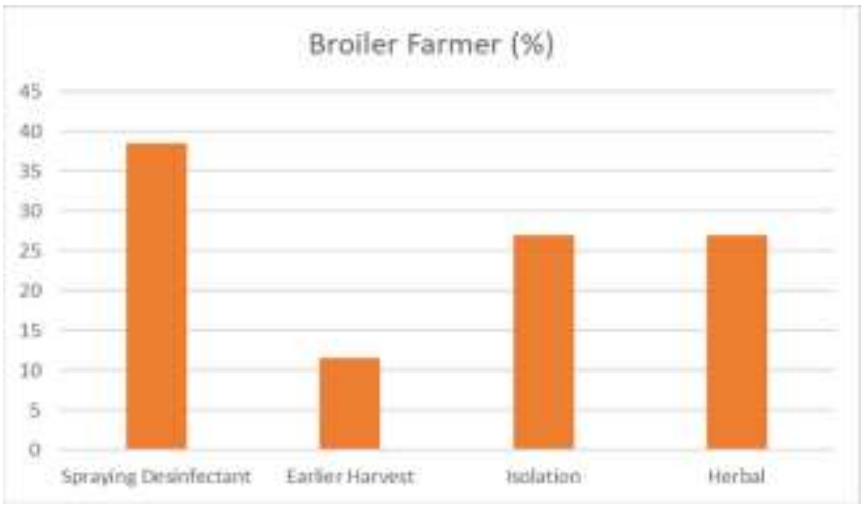

Fig 1. Farmers applied risk management

The results of the study stated that the factor that caused the high risk of partnership broiler production in Blitar, East Java, Indonesia was the death caused by the disease. Diseases that often attack chickens were E. coli, Newcastle Disease (ND), and Gumboro.

Risk management applied to farms includes spraying disinfectants, earlier harvest, isolation, and the use of herbal medicines. As many as $38.46 \%$ of farmers choose to spray disinfectants to avoid the wider spread of the disease. The next risk management undertaken by farmers was to conduct an earlier harvest. This effort was carried out by farmers whose chickens were attacked by diseases and caused high mortality of around $80 \%$ of the population. Early harvesting was the last choice by farmers, especially if the age of chickens was still too small. As many as $11.53 \%$ of farmers make early harvest efforts when their chickens in the maintenance period yesterday were stricken with the disease.

Isolation or separation of farm locations was risk management of production that was mostly done by farmers. $26.92 \%$ of farmers choose to isolate their animals to minimize contracting disease. The isolation or separation of breeding sites aimed to create a broiler breeding environment that was protected from carriers transmitted by humans, fomites, wild animals, infected birds, air, water, etc [18].

Production contracts with longer terms, lower upfront deposit requirements and higher cost sharing with enterprises for technology adoption may make farmers more likely to adopt technology, to adopt technology early and to invest more [19]

Some farmers choose to use herbal medicine to reduce the risk of disease. Farmers in Blitar, East Java, Indonesia were accustomed to providing additional herbal medicine to increase the immune power of the chicken body. Other farmers work to reduce risk by cleaning the surrounding yard, removing wet litter, or sowing husks on wet litter.

\section{Conclusions}

Based on the results of the study it could be concluded that the level of risk of partnership broiler farm production in Blitar, East Java, Indonesia was high. This was caused by the high mortality rate caused by the disease.

The risk management of broiler farm production implemented by farmers in Blitar, East Java, Indonesia focuses on preventing the spread of disease. The applied production risk management was the addition of disinfecting spraying in cages, separating sick animals in isolation cages, providing herbal medicine, cleaning around the cage, and conducting early harvests. 


\section{References}

1. C.B. Barrett, M.E. Bachke, M.F. Bellemare, H.C. Michelson, S. Narayanan, T.F. Walker. World Dev. 40,4:715-730(2012).

https://doi.org/10.1016/j.worlddev.2011.09.006

2. M.F. Bellemare, L. Novak. Am. J. Agric. Econ. 99,2:357-378(2017).

https://doi.org/10.1093/ajae/aaw053

3. H.H. Wang, Y. Wang, M.S. Delgado. Am. J. Agric. Econ. 96,5:1257-1271(2014). https://doi.org/10.1093/ajae/aau036

4. R. Ratnasari, W. Sarengat, A. Setiadi. Animal Agriculture Journal. 4,1: 47-53(2015). [in Bahasa Indonesia]

https://scholar.google.co.id/scholar?hl=id\&as_sdt=0\%2C5\&q=ANALISIS+PEND APATAN+PETERNAK+AYAM+BROILER+PADA+SISTEM+KEMITRAAN+ DI+KECAMATAN+GUNUNG+PATI+KOTA+SEMARANG\&btnG=

5. A.H Hoddi, M.B. Rombe, Fahrul. Jurnal Agribisnis. 10,3:25-32(2011). [in Bahasa Indonesia].

https://scholar.google.co.id/scholar?hl=id\&as_sdt=0\%2C5\&q=ANALISIS+PEND APATAN+PETERNAKAN+SAPI+POTONG+DI+KECAMATAN+TANETE+RI LAU\%2C+KABUPATEN+BARRU+\%28Revenue+Analysis+Cattle+Ranch $+\mathrm{In}+\mathrm{S}$ $\underline{\mathrm{ub}+\text { Tanete}+\mathrm{Rilau}+\text { Barru\&btnG}=}$

6. M. Murthy, S.B. Madhuri. Asia Pacific J. Mark. Manage. Review. 2,5: 58-68(2013). http://indianresearchjournals.com/pdf/APJMMR/2013/May/7.pdf

7. O.R. Iheke, C.A. Igbelina. NJAFE. 12,1:67-74(2016).

https://scholar.google.co.id/scholar?hl=id\&as_sdt=0\%2C5\&q=RISKS+MANAGE MENT+IN+POULTRY+PRODUCTION+IN+IKEDURU+LOCAL+GOVERNM ENT+AREA+OF+IMO+STATE\%2C+NIGERIA\&btnG $=$

8. Sutawi. Kemitraan sebagai strategi manajemen risiko [Partnership as a risk management strategy]. Poultry Indonesia. (2009). [in Bahasa Indonesia]. https://www.semanticscholar.org/paper/Kemitraan-Sebagai-Strategi-ManajemenRisiko-Sutawi/9847cbdc4c540926f09b6eeb83594ed297d8b111\#paper-header

9. H.D. Utami, B.A. Nugroho, U.W. Ningsih, L.E. Radiati, H. Nugroho. J. Adv. Agric. Technol. 5,3:222-226(2018).

https://scholar.google.co.id/scholar?hl=id\&as_sdt=0\%2C5\&q=Broiler+Partnership $\underline{\mathrm{s}+\text { Scheme }+ \text { Advantages }+ \text { toward+Minimising }+ \text { Its }+ \text { Production+and }+ \text { Marketing }+ \text { Ris }}$ $\mathrm{ks}+\mathrm{at}+$ Mojokerto + Indonesia\&btnG $=$

10. D. Crownia, A. Fariyanti. Analisis faktor-faktor yang memengaruhi risiko produksi ayam broiler (Studi kasus: Peternak mitra CV Anjawani Purwakarta). [Analysis of factors affecting the risk of broiler chicken production (Case study: breeder CV CV Anjawani Purwakarta)] [Skripsi] Ekonomi dan Manajemen, Institut Pertanian Bogor. (2017) [in Bahasa Indonesia]. p. 1-61. http://repository.ipb.ac.id/handle/123456789/87344

11. É. Gocsik, A.G.J.M.O Lansink, H.W. Saatkamp. Poult. Sci. 92,12: 3314 3329(2013).

https://doi.org/10.3382/ps.2013-03221

12. A. Fariyanti, N.F.N. Kuntjoro, S. Hartoyo, A. Daryanto. Perilaku ekonomi rumah tangga petani sayuran dalam menghadapi risiko produksi dan harga produk di Kecamatan Pangalengan Kabupaten Bandung. [Economic behavior of vegetable farmer households in facing production risk and product prices in Pangalengan District, Bandung Regency]. [Thesis Phd]. Institut Pertanian Bogor, Jawa Barat, Indonesia (2008). [in Bahasa Indonesia]. p. 178-206.

http://dx.doi.org/10.21082/jae.v25n2.2007.178-206 
13. R. Hafni. Mitigasi risiko dalam pembiayaan murabahah: Studi di PT. BPRS Bhakti Sumekar Kantor Pusat Sumenep. [Risk mitigation in murabahah financing: Study at PT. SRB Bhakti Sumekar Sumenep Head Office] [Thesis] Ekonomi Syariah, UIN Sunan Ampel Surabaya. (2016) [in Bahasa Indonesia]. p. 1-121. https://scholar.google.co.id/scholar?hl=id\&as_sdt=0\%2C5\&q=Mitigasi+Risiko+d alam+Pembiayaan+Murabahah+\%3A+Studi+di+PT.+BPRS+Bhakti+Sumekar+Ka ntor+Pusat+Sumenep\&btnG $=$

14. D. Tanto, S.M. Dewi, S.P. Budio. Rekayasa Sipil. 6,1:69-82(2012). [in Bahasa Indonesia]. https://scholar.google.co.id/scholar?hl=id\&as_sdt=0\%2C5\&q=FaktorFaktor+yang+Mempengaruhi + Produktivitas + Pekerja + pada + Pengerjaan + Atap + Baj a+Ringan+di+Perumahan+Green+Hills+Malang\&btnG $=$

15. A.D. Mahendra, N. Woyanti. Analisis pengaruh pendidikan, upah, jenis kelamin, usia, dan pengalaman kerja terhadap produktivitas tenaga kerja (Studi di industri kecil tempe di Kota Semarang). [Analysis of the effects of education, wages, gender, age, and work experience on labor productivity (Study in tempe small industries in Semarang City)]. [Thesis Phd]. Universitas Diponegoro, Semarang, Indonesia (2014). [in Bahasa Indonesia]. p. 1-70.

https://scholar.google.co.id/scholar?hl=id\&as_sdt=0\%2C5\&q=Analisis+pengaruh + pendidikan $\% 2 \mathrm{C}+$ upah $\% 2 \mathrm{C}+$ jenis + kelamin $\% 2 \mathrm{C}+\mathrm{usia} \% 2 \mathrm{C}+$ dan + pengalaman $+\mathrm{ker}$ ja+terhadap+produktivitas+tenaga+kerja $\% 28 \mathrm{Studi}+\mathrm{di}+\mathrm{industri}+\mathrm{kecil}+$ tempe $+\mathrm{di}+$ $\underline{\text { Kota }+ \text { Semarang\%29\&btnG }=}$

16. Murtiyeni, D. Priyanto, D. Yulistiani, Karakteristik peternak domba atau kambing dengan pemeliharaan digembala atau angon dan hubungannya dengan tingkat adopsi inovasi teknologi [Characteristics of sheep or goat breeders with herding or angon rearing and their relationship with the level of adoption of technology innovation]. Seminar Nasional Teknologi Peternakan dan Veteriner, (Bogor, Indonesia 2005). [in Bahasa Indonesia].

https://scholar.google.co.id/scholar?hl=id\&as_sdt=0\%2C5\&q=karakteristik+Peter nak+Domba+atau+Kambing+dengan+Pemeliharaan+Digembala+atau+Angon+da

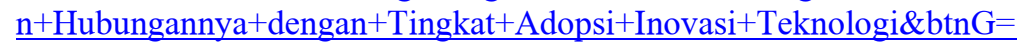

17. N.U. Handayani, M.A. Wibowo, D.P. Sari, Y. Satria, A.R. Gifari. Jurnal Ilmiah Bidang Ilmu Kerekayasaan. 39,2:78-85(2018). [in Bahasa Indonesia]. https://doi.org/10.14710/teknik.v39i2.15918

18. I.B.K. Ardana. Buletin Veteriner Udayana. 3,1:51-59(2011). [in Bahasa Indonesia].

https://scholar.google.co.id/scholar?hl=id\&as_sdt=0\%2C5\&q=STRATEGI+PENC EGAHAN+PENYAKIT+INEFEKSIUS+PADA+PETERNAKAN+BROILER+B ERBASIS+LABORATORIUM\&btnG $=$

19. H. Mao, L. Zhou, J. Ifft, R. Ying. China Econ. Rev. 54:147-159(2019).

https://doi.org/10.1016/j.chieco.2018.10.014 